\title{
Smectite illitization of the Talhar shale, Lower Goru Formation, Southern Indus Basin, Pakistan
}

\author{
Asghar Ali ${ }^{1}$ ] $\cdot$ Muhammad Salman ${ }^{1} \cdot$ Rafique Ahmad $^{2}$
}

Received: 10 March 2021 / Accepted: 3 May 2021 / Published online: 12 May 2021

(c) The Author(s) 2021

\begin{abstract}
Subsurface samples of the Talhar shale, Lower Goru Formation, are analyzed for smectite (montmorillonite) and illite in the Nur-dep\#1 (ND-1), well 2, Southern Lower Indus Basin, Pakistan. The ND-1, well 2 is an unsuccessful well drilled by the OGDCL, Pakistan, for the shale gas exploration. Illitization and elemental content constrained using XRD qualitative and XRF quantitative analyses, respectively. The illite content increases from 15 to $55 \%$ with increasing depth. The fine-grained shale comprises chlorite, kaolinite, halloysite, allophane, muscovite, microcline, illite and montmorillonite. Chlorite was observed at 3450-3452 m, whereas kaolinite is present at depth range of 3450-3482 m. The mix layer expandability decreases from 40 to $20 \%$ at depth ranges from 3450 to $3552 \mathrm{~m}$, respectively. The interstratification is random to ordered. Potassium and silicon contents with respect to aluminum and calcium are increasing with depth. Data obtained in this research indicate that the shale gas is immature and the oil is an early-medium stage of maturation.
\end{abstract}

Keywords Lower Goru Formation · Talhar shale $\cdot$ Illitization $\cdot$ Interstratification $\cdot$ Shale gas

\section{Introduction}

The maturation of hydrocarbon and thermal history of a sedimentary basin can be determined by understanding the intricate processes of diagenesis and low-grade metamorphism of clay minerals (Bruce 1984; Burst 1969). In an organic-rich sedimentary basin, the increase in temperature from 50 to $100{ }^{\circ} \mathrm{C}$ results the solid kerogen to convert into sticky viscous liquid hydrocarbon. The conversion of smectite to illite at 50 to $100{ }^{\circ} \mathrm{C}$ is a crucial reaction that expels liquid hydrocarbon from the source to reservoir rock. Kerogen conversion to liquid hydrocarbon occurs at temperature in which smectite changes to illite by illitization. Smectite contains $40 \%$ water by volume, which sticks the newly produced hydrocarbon in the source rock. Illitization expels water from smectite assisting the migration of hydrocarbon from source rock to reservoir. Apart from illitization, potassium introduced by the breakdown of potash feldspar

Asghar Ali

asghar.ali@uop.edu.pk

1 Department of Geology, University of Peshawar, Peshawar, Pakistan

2 Department of Geology, Bacha Khan University Charsadda, Peshawar, Pakistan or K-rich brines also affects hydrocarbon migration from the source rock (Pytte and Raynolds 1989; Sandler 2006). Montmorillonite, a type of smectite acts as a catalyst in conversion of kerogen to liquid hydrocarbon (John 1985). Illitization occurs in the hydrothermal system via solid-state transformation (SST) or dissolution-crystallization (DC) mechanism. In SST, size and shape of newly formed illite remain similar to smectite (Baronet 1980), whereas in DC polytypes illite grains form (Lazaro 2007).

Conversion of smectite to mix layer smectite to illite and pure illite is the debate area among the geoscientists. Different aspects of the conversion studied by the authors among these effects of temperature, pressure and potassium content are most commonly discussed (Velde et al. 1986; Pollastro 1993). Various studies are carried out on the effect of temperature on illitization during burial diagenesis showing variation due to the regional geothermal gradient.

Pollastro (1993) recognized that temperature is the primary factor in illitization of the hydrocarbon-bearing rocks. According to Pollastro (1993), smectite-illite geothermometer can assist in the evolution of thermal history of a sedimentary basin, tectonic history and changes coincide with the oil window. Therefore, the smectite-illite geothermometer is a useful tool to calculate hydrocarbon potential and thermal maturity. Osborn et al. (2014) studied the 
Cretaceous shale Montana and concluded that illitization may have taken place due to dissolution and precipitation of tectonically derived fluids. The current research focuses on smectite conversion to illite and its effect on hydrocarbon migration from source to reservoir.

\section{Regional geology}

\section{Tectonic setting}

The main sedimentary basins of Pakistan have been divided into the Baluchistan, Pishin and Indus basins based on sedimentation and structural variations (Fig. 1; Kazmi and Jan 1997; Khan et al. 2016). The gigantic Indus basin is further subdivided into the Upper Indus, Central and Lower Indus Basins. The Lower Indus Basin, which is located in the south, consists of the fold and thrust belts of the Kirthar ranges, Sulaiman ranges, Bugti hills, Mari hills and foreland areas of the Indus alluvial (Fig. 1; Williams 1959). Most of the hydrocarbon structural traps and migration paths in the Lower Indus Basin formed due to large-scale extension, during the Indian plate rifting from Madagascar in the Late Cretaceous followed by the Eocene right lateral wrenching (Ahmed et al. 2018). Rifting associated grabens in the Lower Indus Basin during the Cretaceous provided ideal geological structures for the burial diagenesis of clay minerals and maturation of organic contents (Ahmad and Chaudhary 2002; Ahmed et al. 2018).

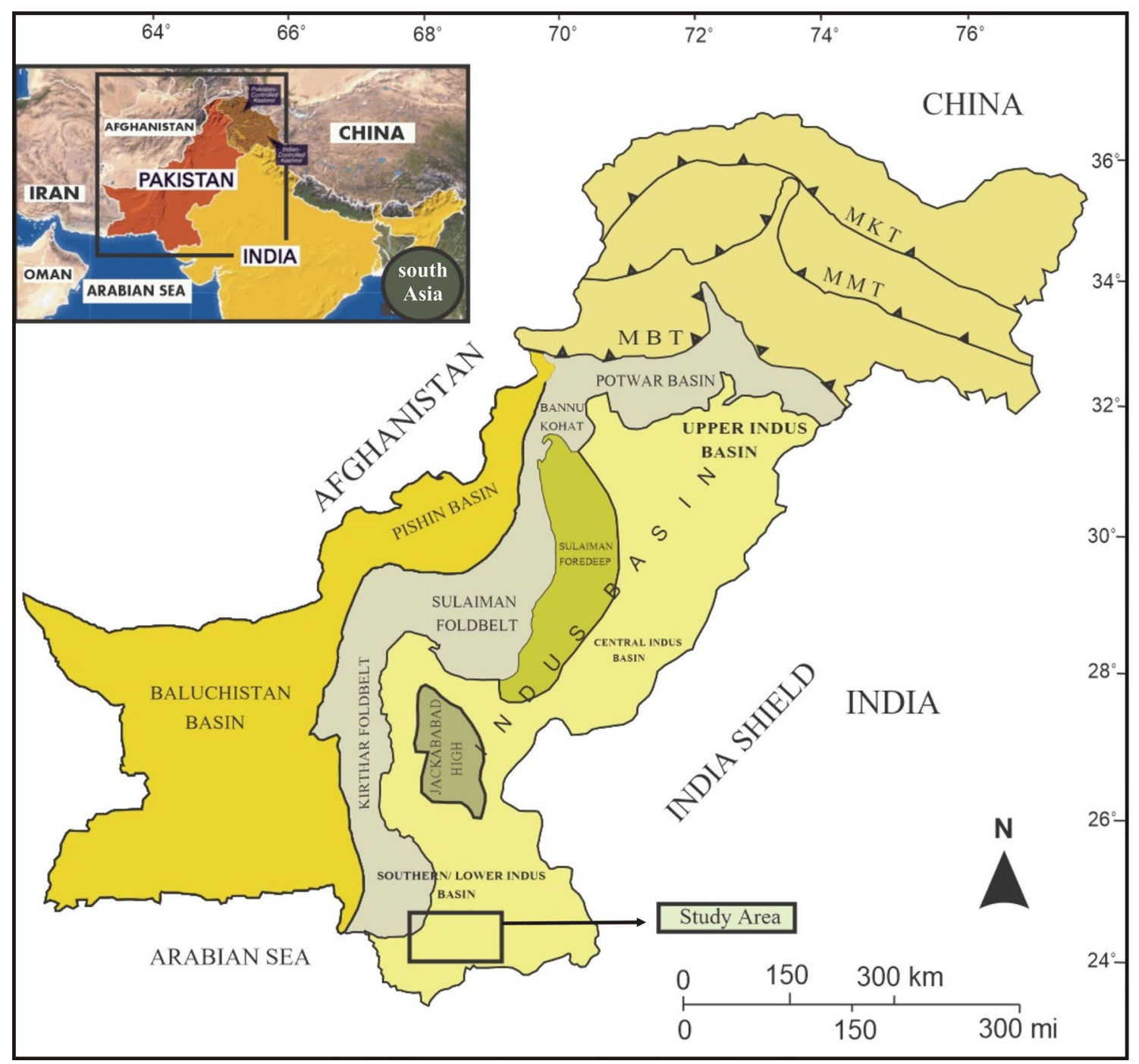

Fig. 1 Simplified tectonic map of Pakistan showing sedimentary basins. Study area located at the Kirthar fold belt of the Lower Indus Basin (after Kazmi \& Jan1997). MBT, Main Boundary Thrust;
MMT, Main Mantle Thrust; MKT, Main Karakoram Thrust. The inset map showing the location of Pakistan 


\section{Stratigraphy}

The Cretaceous stratigraphic sequences of the Lower Indus Basin consist of the Monajhal Group, Pab sandstone and Fort Monro Formation. The Monajhal Group is subdivided into the Sembar Formation, Goru Formation, Parh Limestone and Mughal Kot Formation (Fig. 2; Shah 2009). The Sembar Formation comprises black shale with interbedded siltstone, sandstone and glauconitic shale (Shah 2009). The upper contact of the Sembar Formation is conformable with the Goru Formation, and the lower contact is unconformable with the Chilton Limestone.

The Goru Formation comprises interbedded limestone, shale and siltstone (Fig. 2). At type locality, thickness of the Goru Formation is 1770 feet (Williams 1959). The lower contact of the Goru Formation is conformable with the Sembar Formation, whereas upper contact is transitional with the Parh Limestone. The ND -1 well 2 drilled in the Talhar shale is a member of the Goru Formation (Fig. 3). The Talhar shale is dominated by interbedded shale and sandstone. Thickness of the Talhar shale is $300 \mathrm{~m}$ in the Lower Indus Basin. The Talhar shale has good hydrocarbon generation potential based on the Total Organic Carbon Content (TOC; $1.45-2.44 \%$ ). The generation potential (GP) value ranges from 1.07 to $2.35 \mathrm{mg} \mathrm{HC} / \mathrm{g}$ rock. The values $<2 \mathrm{mg} \mathrm{HC} / \mathrm{g}$ and the GP values $>2 \mathrm{mg} \mathrm{HC} / \mathrm{g}$ for rock indicate a good source rock (Dyman et al. 1996). The Talhar shale is within the zone of hydrocarbon generation (Nazir and Fazeelat 2017; cf. Ahmed et al. 2018).

The Mughal Kot Formation is blackish to grayish hard limestone in the upper part and massive limestone in the lower part (Fig. 2; Shah 2009). At the type section, thickness of the formation is 330 feet (Shah 2009). The lower contact of the Mughal Kot Formation is unconformable with the Parh Limestone; however, conformable contact found around type section area and in Karachi embayment

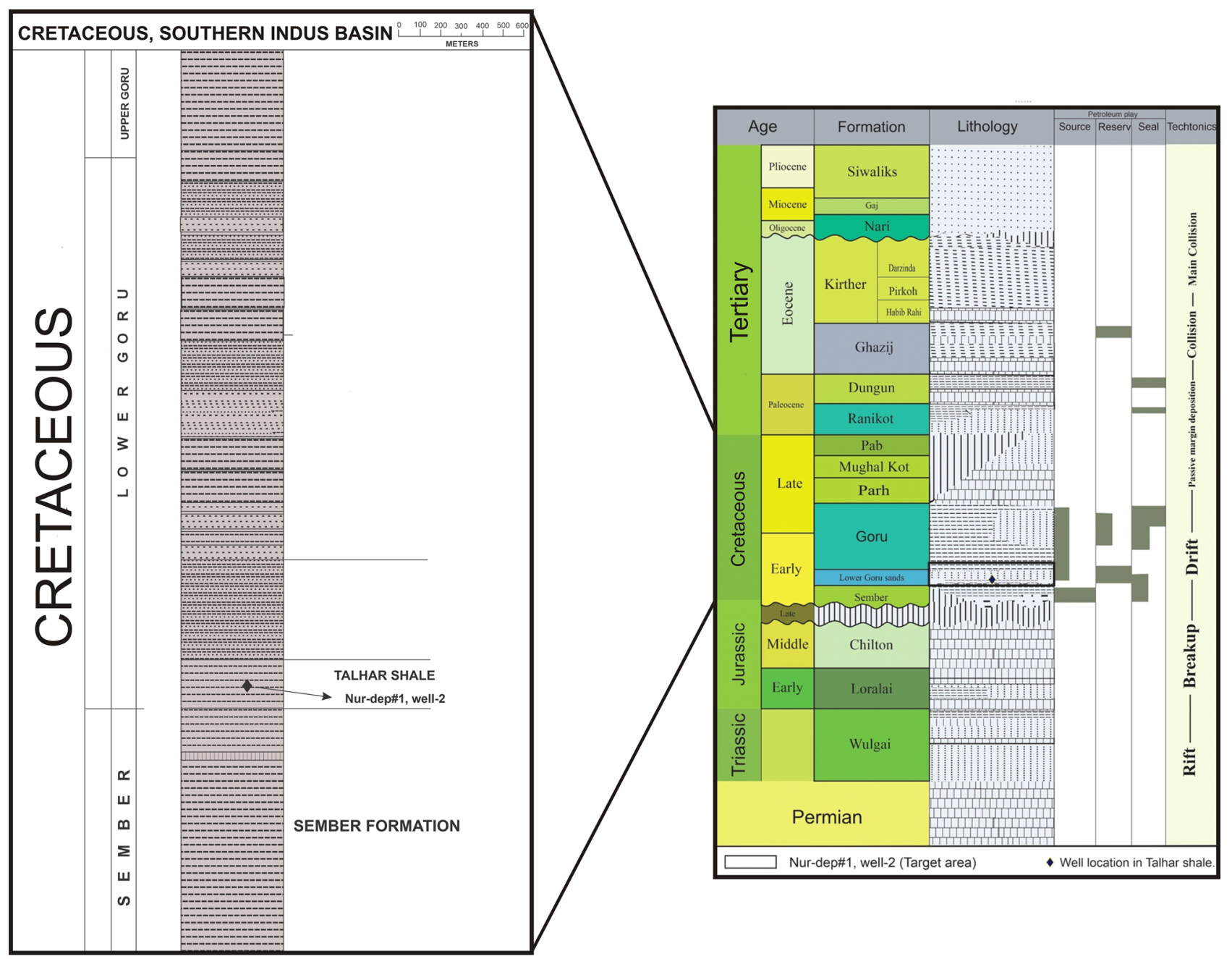

Fig. 2 Generalized and specified stratigraphic columns of the Cretaceous stratigraphic units of the southern Lower Indus Basin. Black diamond showing the well location in the Talhar shale, Lower Goru Formation (after Kadri 1995) 


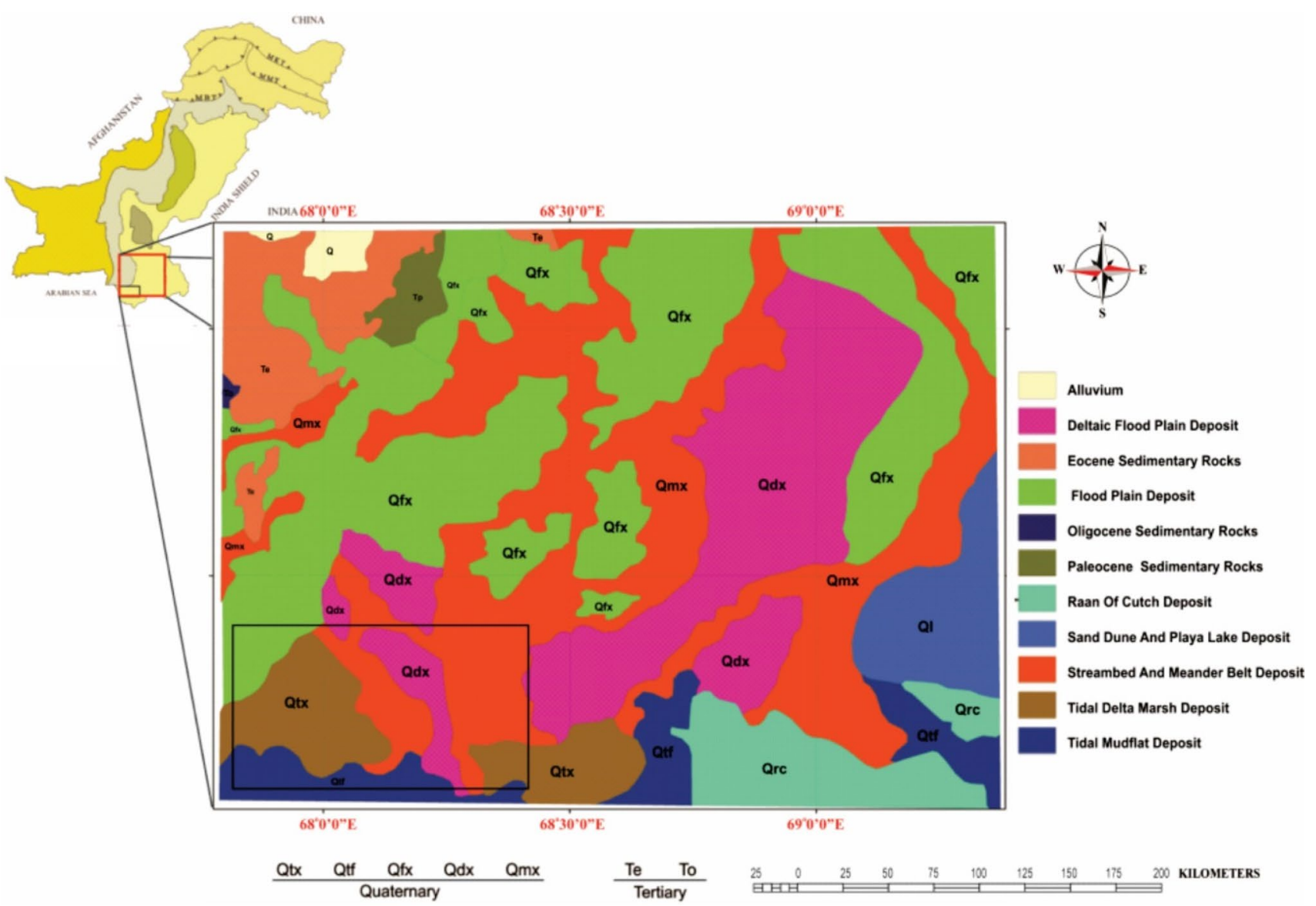

Fig. 3 Geological map of the study area. Rectangle showing the well drilled area. The Inset map showing location of the study area in Pakistan (After Geological Survey of Pakistan, 2012)

(Shah 2009). The Parh Limestone comprises limestone with minor shale and marl beds. Thickness of the Parh Limestone is $\sim 885$ feet at the type section.

\section{Materials and method}

\section{Materials}

A total of six subsurface samples were collected from the ND - 1 well 2 southern Lower Indus Basin (Fig. 3). These samples were analyzed for qualitative and quantitative analyses using X-ray diffraction (XRD) and X-ray fluorescence (XRF), respectively, at the Centralized Resource Laboratory, University of Peshawar, Pakistan. The washed well cutting samples are collected at the depth range of $3450-3512 \mathrm{~m}$ with $2-\mathrm{m}$ interval after each $10 \mathrm{~m}$ obtained from the Talhar shale (Table 1). These samples consist of sands, silt and clays. The washed well cuttings were separated into sand, silt and clay by gravity settling/density separation (see for detail Soukup et al. 2008). Samples were put in $75 \mu$ sieve of mesh size $200 \mathrm{~mm}$ of US standard
Table 1 The study samples names, interval between each depth and depth ranges

\begin{tabular}{lll}
\hline Sample No & Depth interval & Depth range \\
\hline $\mathrm{N}-1$ & $2 \mathrm{~m}$ & $3450-3452 \mathrm{~m}$ \\
$\mathrm{~N}-2$ & $2 \mathrm{~m}$ & $3460-3462 \mathrm{~m}$ \\
$\mathrm{~N}-3$ & $2 \mathrm{~m}$ & $3470-3472 \mathrm{~m}$ \\
$\mathrm{~N}-4$ & $2 \mathrm{~m}$ & $3480-3482 \mathrm{~m}$ \\
$\mathrm{~N}-5$ & $2 \mathrm{~m}$ & $3490-3492 \mathrm{~m}$ \\
$\mathrm{~N}-6$ & $2 \mathrm{~m}$ & $3510-3512 \mathrm{~m}$ \\
\hline
\end{tabular}

and stirred for one minute under the tap water. The clay mixed water was collected in the china dish and placed it in the calm condition for one hour. After settling of clays from water, the water was withdrawn using a $20-\mathrm{ml}$ hypodermic syringe. The retaining clay with some amount of water was separated using funnel and 100-ml beaker. The separated clay was mounted on a hot plate with temperature range of $100-750{ }^{\circ} \mathrm{C}$ to acquire the dry clay for further analysis. 


\section{Methods}

\section{X-ray diffraction analysis}

The XRD analyses were performed on clay samples. The clay samples were analyzed at $0-40^{\circ} 2$ theta range using JDX model 3532 (JEOL, Japan) diffractometer at $40 \mathrm{kV}$ and $30 \mathrm{~mA}$, with $\mathrm{CuK} \alpha$ radiation using $1^{\circ}, 1^{\circ}$ and $2 \mathrm{~mm}$ divergent slit, receiving slit and scattering slit, respectively. The samples were scanned at steep angle $0.050^{\circ}$ and step time of one second. $<1 \mu \mathrm{m}$ grain size was identified using the full width at half maximum and the Scherrer equation. Samples obtained at 3450 to $3512 \mathrm{~m}$ depth at $2 \mathrm{~m}$ interval range contain chlorite, kaolinite, halloysite, allophane, muscovite, microcline, illite and montmorillonite (Fig. 4a-f; Table 1).

\section{X-ray florescence analysis}

The XRF analysis performed on samples $\mathrm{N}-1, \mathrm{~N}-4$ and $\mathrm{N}-6$ to calculate silica, aluminum, potassium and calcium contents. XRF analyses carried out using EDX - 7000 (Shimadzo, UK). The quantitative content estimation of these three samples is calculated in parts per million (ppm) for silica, aluminum, potassium and calcium (Table 2).

\section{Results and discussion}

\section{Extent of illitization}

The current study focuses on smectite (montmorillonite) conversion to illite with depth that causes the expulsion of fluid and silica during illitization, which got increase with depth and leads to smectite-illite mixed layer and illite, respectively (Nadeau et al. 1985; Pevear 1999). In this study, the illite, mix layer smectite-illite peaks vary from 26.2 to $26.82 \theta, 3.32$ to $3.34 \AA$ and montmorillonite varies from 5.6 to $6.32 \theta, 14.1$ to $15.2 \AA$. The chlorite and kaolinite were observed in $\mathrm{N}-1$ obtained at 3450-3452-m-depth interval. These peaks were differentiated at 35 to $36.92 \theta$ and 19.1 to $20.92 \theta$, respectively. Mixed layer of smectite-illite was observed in $\mathrm{N}-1$ and $\mathrm{N}-4$ at 3450-3462 m depth. In addition, the expandability of mixed-layer smectite-illite estimated from Hoffman and Hower, (1979) peak areas decreasing from 40 to $20 \%$.

Recognition of illite in XRD is characterized by a series of peaks of 3.3, 5 and $10 \AA$, respectively (Hillier 2003), and montmorillonite observed at 5.6-6.3 20, and $\AA$, which are comparatively low to illite by examining the total peaks ratio of montmorillonite and illite (Fig. 5). The percent illite calculated using the peak area and intensity (Biscaye 1965),
$10 \%$ percent illite in the low depth sample of 3450-3452 m was calculated by $2 \theta$ values which increase up to $55 \%$ with increasing depth, and this improvement spots the decrease in montmorillonite and increase in illite with depth (Fig. 5). Mixed layer montmorillonite and illite (moderate step during illitization) observed in $\mathrm{N}-1$ and $\mathrm{N}-2$, for which peaks vary from 26.2 to $26.82 \theta$, $\AA$ (Table 3 ). In addition, the expandability of mixed layer smectite-illite estimated from Hoffman and Hower (1979) peak areas decreasing from 40 to 20\% (Tables 2 and 4; Fig. 5).

According to Srodon (1980), the reflection at $5.3 \AA$ and $8.7 \AA$ shows the ordered interstratification. The ordered interstratification recognized in the current study using $5.3 \AA$ and $8.7 \AA$ peaks. The ordered interstratification was identified by Eberl et al. (1978) by the reaction of glass having K, $\mathrm{Al}$ and $\mathrm{Si}$ in three steps. The first step is the reaction within the glass producing $100 \% \mathrm{~K}$-smectite expandable layer followed by reaction with $100 \%$ smectite layer (with increasing temperature and run time) to form illite-smectite ordered and the last step is given below which occurred at temperature range of $260-400^{\circ} \mathrm{C}$.

Smectite-illite $($ random $)+$ kaolinite + quartz $=$ smec tite-illite (ordered) \pm phyrophylite + quartz.

In this step, the alteration of smectite layer illite has been occurred.

\section{Temperature evaluation in the ND-1 well 2}

Since temperature is the main factor in smectite illitization, which can be estimated from the geothermal gradient, estimated average temperature $\left(95^{\circ} \mathrm{C}\right)$ of $\mathrm{ND}-1$ well 2 has been evaluated from the geothermal gradient of the area, proposed by Kadri (1995; Fig. 6).

\section{Effect of potassium availability and illitization temperature}

During illitization, the potassium plays an important role in growing more illite that could be supplied by the breakdown of potassium feldspar (Pusch 1992). Moreover, the temperature and depth enhance the illite growth with the incoming potassium. The increase in potassium content with depth assisting the illitization in ND-1 well 2 (Fig. 7; Table 5). According to Perry and Hower (1970), the high access of potassium could be due to the K-feldspar that alters and disintegrate with increasing depth provides access of potassium to the associated interlayer montmorillonite.

According to Pusch et al. (1987), the potassium oxide value is constant and relatively low above $3 \mathrm{~km}(3000 \mathrm{~m})$ and high below $3.5 \mathrm{~km}(3500 \mathrm{~m})$. The high potassium oxide related to greater depth is due to the loss of K-feldspar at greater depth (Weaver and Beck 1971). The potassium content in the $\mathrm{N}-2, \mathrm{~N}-4$ and $\mathrm{N}-6$ decreases at a depth





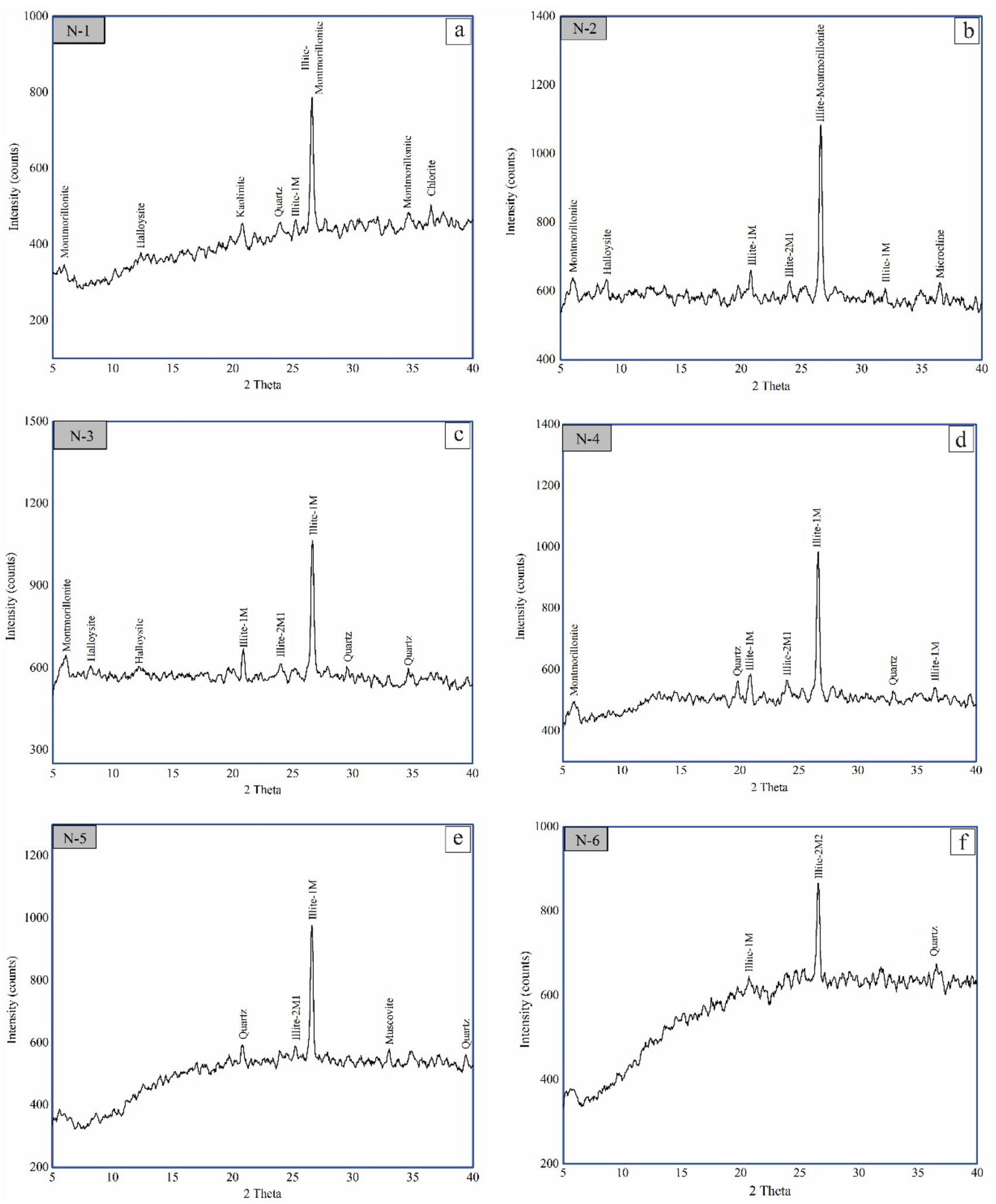

Fig. 4 XRD pattern with d-spacing of $\mathrm{N}-1, \mathrm{~N}-2, \mathrm{~N}-3, \mathrm{~N}-4, \mathrm{~N}-5$ and $\mathrm{N}-6, \mathbf{a}-\mathbf{f}$ showing variation of minerals with depth 
Table 2 XRF analyses of $\mathrm{N}-1, \mathrm{~N}-4$ and $\mathrm{N}-6$

\begin{tabular}{llllll}
\hline Sample No & Depth (m) & Si (ppm) & Al (ppm) & K (ppm) & Ca (ppm) \\
\hline N-1 & $3450-52 \mathrm{~m}$ & 482,611 & 175,331 & 64,153 & 56,647 \\
N-4 & $3480-82 \mathrm{~m}$ & 502,047 & 170,605 & 62,269 & 70,948 \\
N-6 & $3510-12 \mathrm{~m}$ & 537,274 & 158,564 & 59,634 & 54,192 \\
\hline
\end{tabular}

range from 3450 to $3452 \mathrm{~m}, 3480-3482 \mathrm{~m}$ to $3510-3512 \mathrm{~m}$ (Fig. 7).

According to Pusch (1992), the mineralogical reaction occurs as;

Smectite + potassium feldspar + mica $\rightarrow$ illite + quartz + chlorite.

\section{Polytypism in illite}

Burial diagenesis of clay minerals causes variation in mineralogy and morphological characteristics of illite by solid-state transformation and dissolution followed by recrystallization with increasing depth (Lazaro 2007). DC mechanism causes morphological variation in the polytypes of daughter mineral illite after the dissolution of parent minerals smectite (montmorillonite; Baronnet 1980).
Table 3 The d-spacing of the minerals

\begin{tabular}{ll}
\hline Mineral Constituents & D-spacing \\
\hline Illite & $3.3,4.8,10.1$ \\
Montmorillonite & $14.1,15.2$ \\
Mixed layer I/M & $3.32,3.34$ \\
Quartz & $3.21,3.71$ \\
\hline
\end{tabular}

Table 4 Percent expandability, $2 \theta\left(^{\circ}\right)$ and peak width $(\AA)$

\begin{tabular}{lllll}
\hline $\begin{array}{l}\text { Percent } \\
\text { expend- } \\
\text { ability }\end{array}$ & $2 \theta\left(^{\circ}\right)$ & Peak Width $(\AA)$ & $2 \theta\left(^{\circ}\right)$ & Peak Width $(\AA)$ \\
\hline 20 & 8.92 & 9.91 & 17.19 & 5.15 \\
40 & 9.43 & 9.37 & 16.58 & 5.34 \\
\hline
\end{tabular}

Generally, the term illite encompasses a series of Al- and $\mathrm{K}$-bearing dioctahederal minerals. Five illite polytypes has been recognized; $1 \mathrm{M}, 2 \mathrm{M}_{1}, 2 \mathrm{M}_{2}, 1 \mathrm{M}_{\mathrm{d}}$ and $3 \mathrm{~T}$ based on fixed tetrahedral sheet with variation in the layer stacking sequence (Boles et al. 2018). XRD analyses indicate that the Talhar shale illite consists of $1 \mathrm{M}$ and $2 \mathrm{M}_{1}$ polytypes. $1 \mathrm{M}$ has been recognized in all samples, whereas $2 \mathrm{M}_{1}$ is missing in N-4 (Fig. 4).
Fig. 5 The stacked pattern of the XRD pattern, showing the percent illite increasing with depth. Quartz and illite peak distinguished with 20 20.4-20.9 and 23.9-24.3, respectively. The illite and I/M peak, observed at 26.4-26.7 $2 \theta$

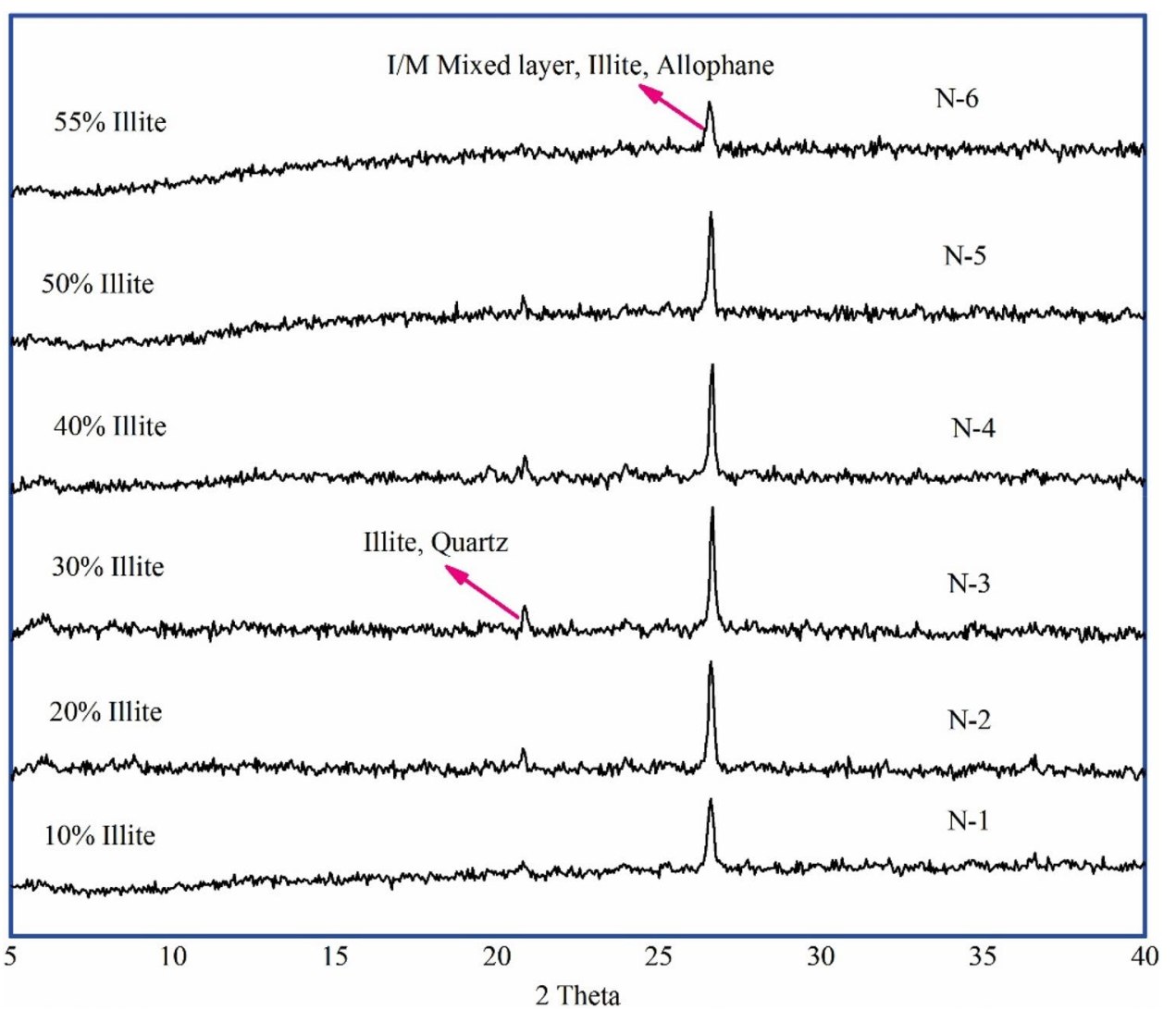




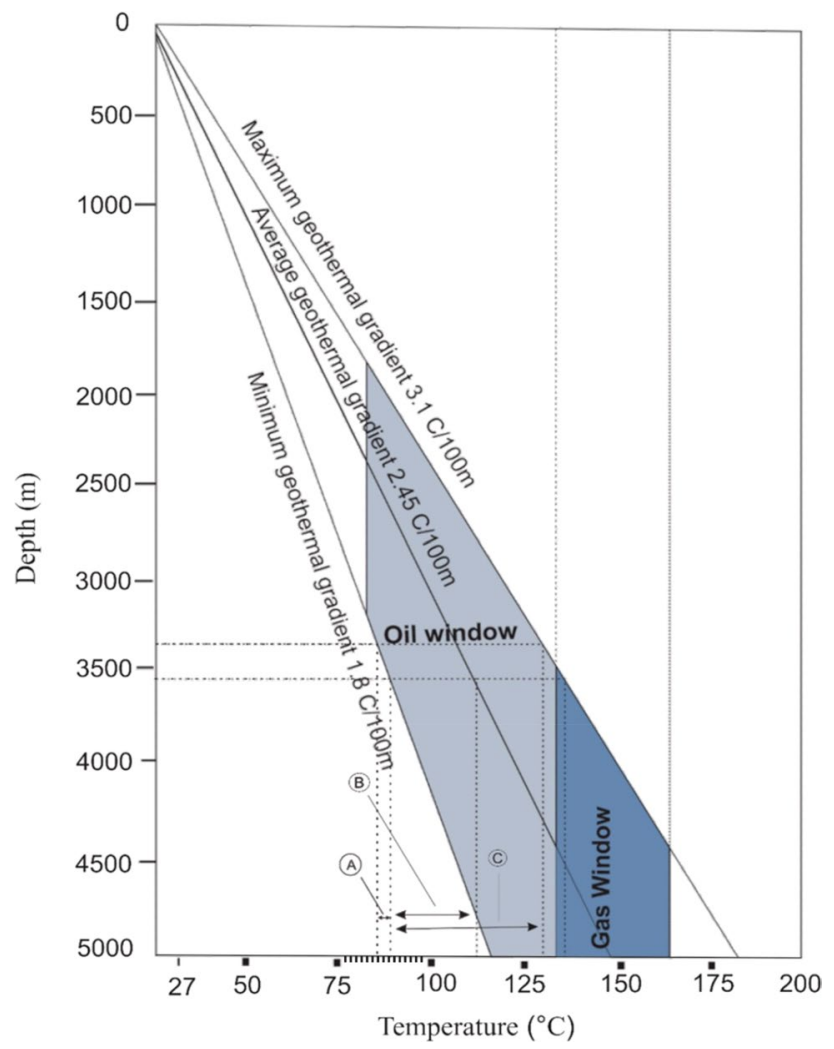

Fig. 6 Geothermal gradients in the Kirthar region with depth, the evaluated temperature shown with the dotted lines. A represents minimum, $\mathrm{B}$ average and $\mathrm{C}$ for high geothermal gradient. ND-1 well 2 temperature represented by $\mathrm{B}$. A represents the temperature range of Talhar shale in ND-1 well 2 which is $80{ }^{\circ} \mathrm{C}$ up to $95{ }^{\circ} \mathrm{C}$ (modified after Khan and Raza 1986)



Fig. 7 Potassium weight percent with depth in the ND-1 well 2, Lower Indus Basin, Pakistan. Potassium content is decreasing with depth
Table 5 The potassium content in ND -1 well 2

\begin{tabular}{ll}
\hline Sample No & Potassium content \\
\hline $\mathrm{N}-1$ & $64,153 \mathrm{ppm}$ \\
$\mathrm{N}-4$ & $62,269 \mathrm{ppm}$ \\
$\mathrm{N}-6$ & $59,634 \mathrm{ppm}$ \\
\hline
\end{tabular}

\section{Discussion}

Most of the hydrocarbon wells drilled in the Lower Indus Basin are producing, whereas non-producing wells also exist in the area. Burial diagenesis of organic rich materials leads to the kerogen formation that store in the structural traps of low permeability sealed rocks. Low illitization and potassium availability may render the liquid kerogen migration as the kerogen sticks to the smectite. The geothermal gradient of Kirthar region is $1.8^{\circ} \mathrm{C} / 100 \mathrm{~m}$, from which the temperature of ND-1 well 2 evaluated as $80-95^{\circ} \mathrm{C}$ (Fig. 6). The evaluated temperature of ND-1 well 2 as $\sim 80-95{ }^{\circ} \mathrm{C}$ mentions that the smectite-illitization might has been occurred in the area (Figs. 4 and 5). Increase in temperature with depth affects smectite-illitization and plays key role in hydrocarbon maturation (Pollastro 1993). The Pollastro (1993) diagenetic model has been adopted in this research to estimate the maturity of hydrocarbon. The smectite-illite mixed layer interstratification (R0) identified with the help of XRD shows immature gas and oil maturation of medium stages (Fig. 7). Similarly, the potassium content is important for illitization, which enters interlayer smectite and the high ratio between smectite layer and potassium leads to illitization. Potassium availability and temperature are two interrelated factors during illitization, high access of potassium, and high temperature leads to high illitization with respect to low potassium availability or low temperature. ND-1 well 2 has high access of potassium > 3000 ppm with comparatively low temperature. The high potassium content in the area might be the result of the microcline detected in XRD analysis for ND-1 well 2 .

Likewise depth is important for smectite-illitization because burial pressure with depth causes decrease in mixed layer expandability of smectite-illite and illite percent increases that leads to the expulsion of fluid that aids in migration of hydrocarbon. The mixed-layer expandability in ND-1 well 2 has decreased from 40 to $20 \%$, which led to increase the illite percent from 10 to $55 \%$. Two illite polytypes exist in samples with depth, which are illite $1 \mathrm{M}$ and $2 \mathrm{M}_{1}$. The $1 \mathrm{M}$ polytype occurs as diagenetic product and $2 \mathrm{M}_{1}$ occurs as the weathering product of shale and schist. $1 \mathrm{M}$ polytype detected in all samples at ND-1 well 2 suggests the diagenetic nature of shale (cf. Pevear 1999). According to Pevear (1999), 1 M polytype of illite is exclusively diagenetic and $2 \mathrm{M}_{1}$ polytype comes from the eroded detrital mica schist, phyllite and slates. The $1 \mathrm{M}$ polytype 
grows first, which feeds the cations to the $2 \mathrm{M}_{1}$ growth in a narrow temperature range of $80-120{ }^{\circ} \mathrm{C}$ (Baronnet 1980; Inoue et al. 1988). The occurrence of $1 \mathrm{M}$ polytype with $2 \mathrm{M}_{1}$ illite indicates the diagenetic nature of shale.

The potassium content in the $1 \mathrm{M}$ polytype is low as compared to $2 \mathrm{M}_{1} .1 \mathrm{M}$ polytype occupy both cis and trans sites of Dioctahederal (2:1) layer; however, $2 \mathrm{M}_{1}$ occupy only cis vacant sites of Dioctahederal (2:1) layer (Pevear 1999). $1 \mathrm{M}$ polytype illite occurs at 55\% expandable layer (montmorillonite) and below, whereas $2 \mathrm{M} 1$ polytype occurs at $20 \%$ expandable layer. Both polytypes range up to $0 \%$ montmorillonite expandable layer (Figs. 4, 5). The $1 \mathrm{M}$ illite occurs at a depth range of $3450-3452 \mathrm{~m}$ which shows the high expandable layer that is $\leq 40 \%$ at the average temperature which is $\sim 80-95^{\circ} \mathrm{C}$ (Ehsan et al. 2018).

\section{Hydrothermal alteration}

Fluids play a key role in alteration of smectite to illite. Whitney (1990) assumed that pore water chemistry is related to permeability which is an important agent in the illitization, which allows the access of potassium to the illitization.

ND-1 well 2 located in the Lower Indus basin acquires the dissolution and crystallization with the temperature range of $80-95{ }^{\circ} \mathrm{C}$ with access to a better proportion of potassium. The calcium evaluated from the X-ray fluorescence varies with the depth; the calcium in the depth range $(3450-3452 \mathrm{~m}$ ) is 3.775 and changes to $4.391-3.725$ at the depth range of $3480-82 \mathrm{~m}$ to $3510-12 \mathrm{~m}$, respectively. The aluminum oxide is decreasing with the increasing depth as 21.610-20.243-16.512, respectively, which is provided by the cannibalization process (dissolution of smectite) (cf. Boles and Franks 1979). The Al content in the illitization process is provided by the feldspar dissolution; however, the cannibalization is the main provider and the dissolution potassium feldspar is a much lesser provider in reaction (Christidis 1995). The Al content in the samples decreasing corresponds to the decreases in the layer expandability with depth. The presence of halloysite in samples $\mathrm{N}-1, \mathrm{~N}-2$ and $\mathrm{N}-3$ and allophane in sample $\mathrm{N}-5$ also predicts the hydrothermal alteration product of the weathered volcanic glass in the area (Jackson 1957).

\section{Comparison of oil, gas window and illitization}

Burial diagenesis causes alteration of minerals and organic constituents (Tissot and Espitalie 1975). The kerogen genesis occurs in the presence of a catalyst (montmorillonite) at 50 to $60{ }^{\circ} \mathrm{C}$ (Fig. 8). Similarly conversion of montmorillonite to smectite-illite decreases clays expandability with depth, leading to increase the illitization process.

The Talhar shale in the Lower Indus Basin contains montmorillonite with better absorption quality on both

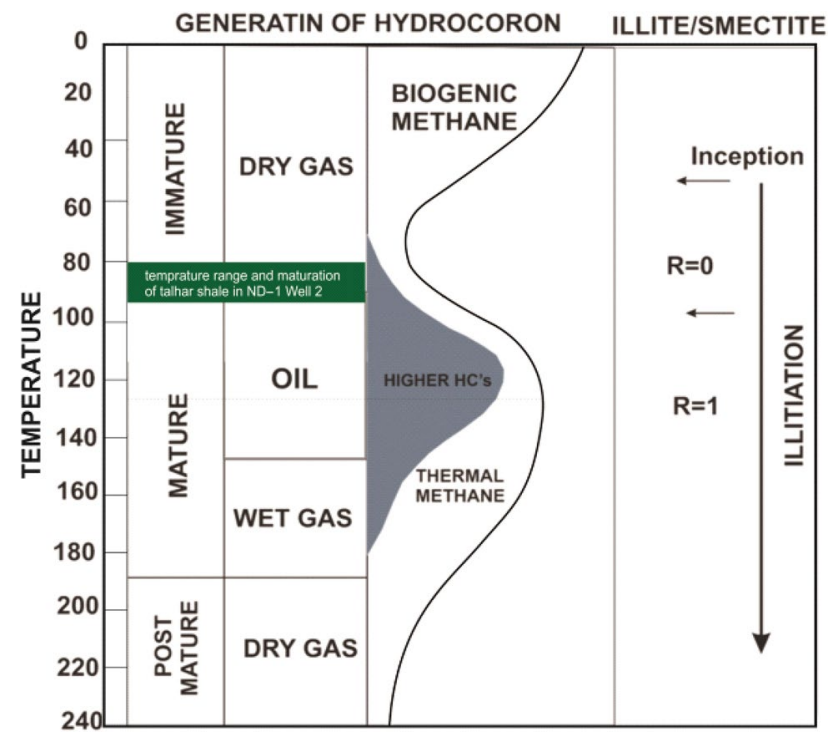

Fig. 8 The stage of maturation in the current ND-1 well 2, showing the initial stages of maturation, and the dry gas is immature. The rectangle showing temperature range (Modified after Pollastro1993)

internal and external surfaces (Ehsan et al. 2018). In addition, the illite grows with depth by DC mechanism. According to the analysis of ND-1 well 2 samples, the growth of polytypic illite from at depth range of $3450-3452 \mathrm{~m}$. The maturity of hydrocarbon may estimate through TOC, Tmax and vitrinite reflectance experimental techniques. According to Ehsan et al. (2018) and Robinson et al. (1999), the TOC of Talhar shale, Lower Indus Basin, is $2.35-2.84 \%$ and vitrinite reflectance of $0.500 .55 \%$ indicating the low maturity of hydrocarbon. These observations are sophisticated for successful hydrocarbon maturation, but the smectite illitization will further refine the maturity.

The illitization with depth starts at a temperature range of $\sim 50-60{ }^{\circ} \mathrm{C}$ and coincides with the kerogen maturation, which leads to the oil window. Different oil windows have been estimated in the Lower Indus basin occurring above $3000 \mathrm{~m}$ (Fig. 8). The oil window distribution in the Lower Indus Basin occurs at various depths, indicating difference in temperature versus depth. These distributions are affected by duplex structure architecture of traps in the basin after the right lateral wrenching of the Indian plate in the Eocene (Ahmed et al. 2018). The oil window in the ND-1 well 2 is identified at temperature range $\sim 80-95{ }^{\circ} \mathrm{C}$, using the illitization process and the Pollastro (1993) diagenetic window. The interstratification of mixed layer smectite (montmorillonite)-illite is used for the maturation of hydrocarbon. The oil window of ND-1 well 2 occurs at temperature range $80-95{ }^{\circ} \mathrm{C}$ (Figs. 8, 9). Based on oil window, it is appraised that in the Lower Goru Formation the oil window is relatively deeper (Fig. 8). Based on the above observations, the

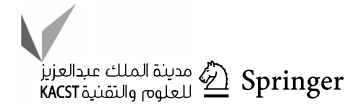


Fig. 9 The oil window encountered by different drilled wells indicate that it mostly occurs at the Cretaceous strata with its extension into the Jurassic. The ND -1 well 2 oil window show in black (after Kadri 1995)

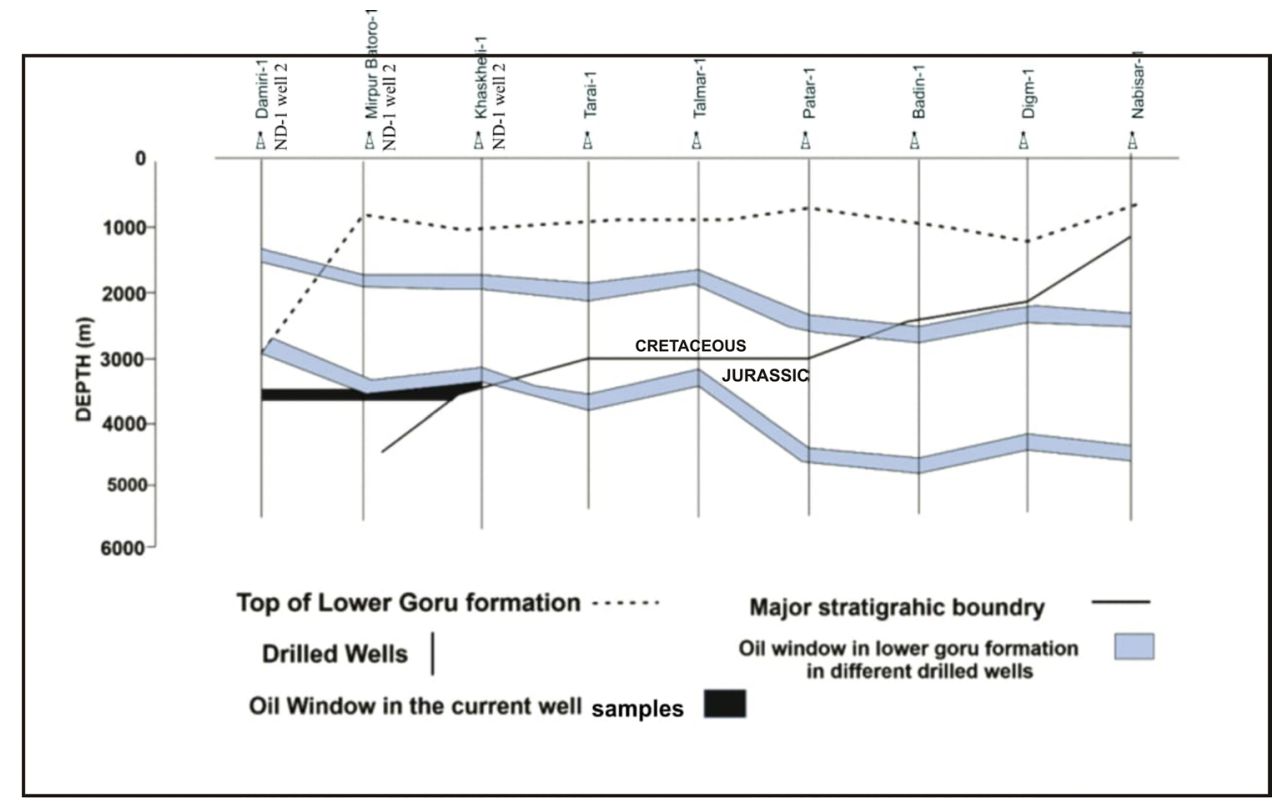

ND-1 well 2 is unsuccessful hydrocarbon well due to maturation of hydrocarbon.

\section{Conclusions}

The Talhar shale of the Goru Formation in the Lower Indus basin (Southern Kirthar region) was studied for the shale gas potential in context of smectite illitization. It is confirmed after the XRD and XRF analysis that illitization has been occurred in ND-1 well 2.• $\mathrm{T} \mathrm{h}$ e illite increased from 10 to 55 percent at the depth range of 3450-3512 $\mathrm{m}$ during burial diagenesis. $1 \mathrm{M}$ and 2M1 polytypes of illite show the dissolution and precipitation mechanism with depth in the ND-1 well 2. Smectite (montmorillonite)-illite mixed layer expandability in the temperature range of $80-95{ }^{\circ} \mathrm{C}$ decreased from 40 to $20 \%$ with increasing depth.

- Potassium availability, temperature and depth studied are important factors for illitization. The access to potassium is greater but the temperature is comparatively low which led to random interstratification (R0) of I/M mixed layer.

- The random interstratification (R0), which is associated with low temperature used for the estimation of maturity of hydrocarbon.

- It is estimated after plotting the obtained results of ND-1 well 2 in the Pollastro (1993) that the gas is immature and the oil is not well developed (medium stages of maturation).

- It is suggested that future studies should examine the roles of over-pressure development and micro-fracturing on hydrocarbon migration.
Funding We appreciate the Department of Geology and Centralized Resource Laboratory, University of Peshawar for research facilities. We thank Manager Exploration OGDCL, for providing the well cuttings for this research.

Open Access This article is licensed under a Creative Commons Attribution 4.0 International License, which permits use, sharing, adaptation, distribution and reproduction in any medium or format, as long as you give appropriate credit to the original author(s) and the source, provide a link to the Creative Commons licence, and indicate if changes were made. The images or other third party material in this article are included in the article's Creative Commons licence, unless indicated otherwise in a credit line to the material. If material is not included in the article's Creative Commons licence and your intended use is not permitted by statutory regulation or exceeds the permitted use, you will need to obtain permission directly from the copyright holder. To view a copy of this licence, visit http://creativecommons.org/licenses/by/4.0/.

\section{References}

Ahmad N, Chaudhry S (2002) Kadanwari gas field, Pakistan: a disappointment turns into an attractive development opportunity. Pet Geosci 8(4):307-316

Ahmed S, Solangi SH, Jadoon MSK, Nazeer A (2018) Tectonic evolution of structures in Southern Sindh Monocline, Indus Basin, Pakistan formed in multi-extensional tectonic episodes of Indian Plate. Geod Geodyn 9(5):358-366

Baronnet A (1980) Pollytypism in micas: a survey with emphasis on the crystal gowth aspect. In: Kaldis E (ed) Current topics in materials science. North Holland, Amsterdam, pp 447-548

Biscaye PE (1965) Mineralogy and sedimentation of recent deep-sea clay in the Atlantic Ocean and adjacent seas and oceans. Geol Soc Am Bull 76:803-832

Boles JR, Franks SG (1979) Clay diagenesis in Wilcox sandstones of southwest Texas: implications of smectite diagenesis on sandstone cementation. J Sediment Res 49(1):55-70 
Boles A, Schleicher AM, Solum J, Pluijm BV (2018) Quantitative X-Ray powder diffraction and the illite polytype analyses method for direct fault rock dating: a comparison of analytical technique. Clays Clay Miner 66(3):220-232

Bruce CH (1984) Smectite dehydration-its relation to structural development and hydrocarbon accumulation in northern Gulf of Mexico basin. AAPG Bull 68(6):673-683

Burst JF (1969) Diagenesis of gulf coast clayey sediments and its possible relation to petroleum migration. AAPG Bull 53(1):73-93

Christidis GE (1995) Mechanism of illitization of bentonites in the geothermal field of Milos Island Greece: Evidence based on mineralogy, chemistry, particle thickness and morphology. Clays Clay Miner 43(5):569-585

Dyman JG, Palacas RG, Tysdal WJ, Perry Jr, Pawlewicz MJ (1996) Source rock potential of middle cretaceous rocks in southwestern Montana. AAPG Bull 80:1177-1183

Eberl D, Whitney G, Khoury H (1978) Hydrothermal Reactivity of Smectite. Am Mineral 63:401-409

Ehsan M, Hanming G, Akhtar MM, Abbasi SS, Ullah Z (2018) Identification of hydrocarbon potential of talhar shale: member of lower goru formation using well logs derived parameters, Southern Lower Indus Basin. Pak J Earth Sci 29(3):587-593

Hillier S (2003) Quantitative analysis of clay and other minerals in sandstones by X-ray powder diffraction (XRPD). In: Worden RH, Morad S (eds) Clay Mineral Cements in Sandstones. Association of Sedimentalogists, Special Publications, Wiley-Blackwell, Oxford, vol 34, pp 213-251

Hoffman J, Hower J (1979) Clay mineral assemblages as low grade metamorphic geothermometers: application to the thrust faulted disturbed belt of Montana, U.S.A. In: Scholle PA, Schluger PS (eds) Aspects of diagenesis. Special Publication, SEPM Society for Sedimentary Geology, pp 55-79

Inoue A, Velde B, Meunier A, Touchard G (1988) Mechanism of illite formation during smectite-to-illite conversion in a hydrothermal system. Am Mineral 73:1325-1334

Jackson ML (1957) Frequency distribution of clay minerals in major great soil groups as related to the factors of soil formation. Clays Clay Miner 6:133-143

John PM (1985) Rb-Sr evidence for punctuated illite/smectite diagenesis in the Oligocene Frio Formation. Tex Gulf Coast Geol Soc Am 96(1):144-122

Kadri IB (1995) Petroleum geology of Pakistan. Pakistan Petroleum Limited, Karachi, p 273

Kazmi AH, Jan MQ (1997) Geology and Tectonics of Pakistan Graphic. Pakistan, Karachi, p 554

Khan MA, Raza HA (1986) The role of geothermal gradients in hydrocarbon exploration in Pakistan. J Pet Geol 9(3):245-258

Khan M, Nawaz S, Shah M, Hasan M (2016) Interpreting seismic profiles in terms of structure and stratigraphy, an example from Lower Indus Basin Pakistan. Universal Journal of Geoscience 4(3):62-71

Lazaro VV (2007) Illitization processes: series of dioctahedral clays and mechanisms of formation. Diagenesis and low-temperature metamorphism. theory. Method Reg Asp Semin SEM 3:31-39

Nadeau PH, Wilson MJ, McHardy WJ, Tait JM (1985) The conversion of smectite to illite during diagenesis: evidence from some illitic clays from bentonites and sandstones. Mineral Mag 49(352):393-400

Nazir A, Fazeelat T (2017) Geochemical characterization of cretaceous sediments-Sindh Basin, Pakistan. Energy Sour, Part a: Recovery, Utilization, and Environ Effects 39(4):406-413

Osborn SG, Duffield LT, Elliott WC, Wampler JM, Elmore RD, Engel MH (2014) The timing of diagenesis and thermal maturation of the cretaceous marias river shale, disturbed belt, Montana. Clays Clay Miner 62:112-125

Perry E, Hower J (1970) Burial diagenesis in Gulf Coast pelitic sediments. Clays Clay Miner 18(3):165-177

Pevear DR (1999) Illite and hydrocarbon exploration. Proc Natl Acad Sci 96(7):3440-3446

Pollastro RM (1993) Considerations and applications of the illitesmectite geothermometer in hydrocarbon-bearing rocks of Miocene to Mississippian age. Clays Clay Miner 41(2):119-133

Pusch R (1992) Investigations of a clay profile on southern Gotland of presumed value for documentation of smectite/illite conversion. SK.B Arbetsrapport Swedish Nuclear Fuel and Waste Management Co., Stockholm, pp 92-74

Pusch R, Borgesson L, Erlstrom M (1987) Alteration of isolating properties of dense smectite clay in repository environment as exemplified by seven pre-Quaternary clays. SKB Technical Report TR SKB, Stockholm, Sweden, pp 87-29

Pytte A, Reynolds RC (1989) The thermal transformation of smectite to illite. Thermal Histories of Sedimentary Basins. Springer-Verlag, Berlin, pp 133-140

Robinson CR, Smith MA, Royle RA (1999) Organic Facies in cretaceous and jurassic hydrocarbon source rocks Southern Indus Basin Pakistan. Int J Coal Geol 39(1-3):205-225

Sandler A (2006) Estimates of atmospheric $\mathrm{CO}_{2}$ levels during MidTuronian derived from stable isotope composition of paleosol calcite from Israel. GSA Special Paper 46:75-88

Shah SMI (2009) Stratigraphy of Pakistan. Geol Surv Pak Mem 22:381

Soukup DA, Buck BJ, Harris W (2008) Preparing soils for mineralogical analyses. methods of soil analysis part 5. Mineralogical Methods 5:13-31

Srodon J (1980) Precise identification of illite/smectite interstratification by X-ray powder diffraction. Clays Clay Miner 28:401-411

Tissot BP, Espitalie J (1975) Thermal evolution of organic matter in sediments: application of a mathematical simulation petrleum potential of sedimentary basins and reconstructing the thermal history of sediments. Oil Gas Sci Technol Rev 30:743-777

Velde B, Suzuki T, Nicot E (1986) Pressure-temperature- composition of illite/smectite mixed-layer minerals: niger delta mudstones and other examples. Clays Clay Miner 34:435-441

Weaver CE, Beck KC (1971) Clay-water diagenesis during burial: how mud becomes gneiss. Geological Society of America Special Paper, vol 134, pp 96. https://doi.org/10.1130/SPE134

Whitney G (1990) Role of water in the smectite-to-illite reaction. Clays Clay Miner 38(4):343-350

Williams MD (1959) Stratigraphy of the Lower Indus Basin, west Pakistan. Progress 5 World Pet Cong 19:377-391 